\title{
Kerjasama Australia dan Indonesia dalam Upaya Pengembangan Sektor Pendidikan Di Australia Melalui Organisasi ACICIS (Australian Consortium For In-Country Indonesian Studies)
}

\author{
Ismiyatun $^{1}$ dan Diah Ariyanti ${ }^{2}$ \\ ${ }^{1}$ Dosen Hubungan Internasional, Fisip Unwahas dan ${ }^{2}$ Mahasiswa tingkat akhir Hubungan \\ Internasional, Fisip Unwahas \\ Email : ismyunwahas@gmail.com
}

\begin{abstract}
This study analyzes the collaboration between Australia and Indonesia in the development of the education sector in Australia through the ACICIS (Australian Consortium for In-Country Indonesian Studies) organization which was established in 1994. ACICIS is a consortium of non-profit universities that develops and coordinates various study options quality in Indonesia for Australian, non-Australian and individual students. The reason Australia and Indonesia collaborate in the education sector is to improve the quality and quality of education in both countries, at the university level. In this journal, we discuss how cooperation between Australia and Indonesia in the education sector through the ACICIS organization. To find out the system of cooperation between the two parties, in carrying out this collaboration, researchers used an approach to the theory of international cooperation. Keywords: ACICIS (Australian Consortium for In-Country Indonesian Studies), international cooperation, education.
\end{abstract}

\section{A. Pendahuluan}

Dalam menghadapi revolusi industri 4.0, sektor pendidikan yang baik dan berkualitas memainkan peran penting untuk mendukung dan meningkatkan daya saing dari suatu negara. Peranan pendidikan sangat berpengaruh juga dalam pembangunan suatu negara karena negara yang maju sudah pasti memiliki mutu pendidikan yang sangat baik di negeranya. Negara yang mempunyai generasi penerus yang cerdas pasti para penerusnya akan memperbaiki pembangunan terhadap negaranya. Pendidikan sangatlah penting untuk menentukan kedudukan suatu negara. Ilmu pengetahuan teknologi suatu negara juga mempengaruhi kemajuan negara. ${ }^{1}$

Contoh seperti pendidikan di negara Australia, di Australia sektor pendidikan itu merupakan salah satu sektor yang sangat diperhatikan oleh pemerintah. Sampai-sampai setiap anak yang terlahir di Australia memiliki kewajiban untuk bersekolah. Bahkan pemerintah Australia tidak segan-segan memberi sanksi terhadap orang tua, jika anaknya

\footnotetext{
1 https://www.ristekdikti.go.id/siaran-pers/pengembangan-iptek-dan-pendidikan-tinggi-di-era-revolusi-industri4-0/, diakses pada 15 Juni 2019, pukul 00.11 wib.
} 
sering membolos dan malas untuk bersekolah, jadi tidak heran jika masyarakat Australia mayoritas berpendidikan.

Hal ini juga, yang membuat negera Australia menjadi salah satu negara favorit dunia untuk melanjutkan pendidikan. Terutama bagi mereka yang ingin melanjutkan pendidikan ke tingkat yang lebih tinggi semisal di tingkat universitas. Untuk meningkatkan sistem pendidikan yang ada di Australia, pihak Australia juga bekerjasama dengan negara lain. Salah satunya adalah negara Indonesia. Kerjasama ini perlu dilakukan karena melalui kerjasama ini pihak Australia dapat mempelajari sistem pendidikan yang ada di Indonesia, sehingga pengetahuan negara Australia tidak hanya berfokus pada sesuatu hal yang ada di Australia saja. Selain mempelajari sistem pendidikan yang ada di Indonesia, pihak Australia juga dapat berkesempatan untuk mempelajari berbagai budaya dari negara Indonesia, serta dapat menikmati beragam cita rasa makanan khas Indonesia.

Kerjasama ini diwujudkan dengan di dirikannya organisasi ACICIS (Australian Consortium for In-Country Indonesian Studies). ACICIS merupakan sebuah lembaga konsorsium non-prit yang inovatif, nirlaba, serta bertujuan untuk memudahkan mahasiswa asing khususnya mereka yang berasal dari Australia, untuk melakukan studi di universitas-universitas Indonesia. Melalui ACICIS ini para mahasiswa dapat mendapatkan pengalaman pendidikan terbaik di Indonesia, dengan kondisi lingkungan yang aman, dan mendukung. ${ }^{2}$ ACICIS juga dapat meningkatkan pengalaman pendidikan mahasiswa, dan menghasilkan lulusan dengan kemampuan untuk memahami dunia dari perspektif global. ACICIS didirikan ketika Universitas Murdoch memperoleh dukungan dari Australian Departement of Employment, Education and Training (DEET) untuk mendirikan konsorsium nasional yang berkoordinasi dengan program pendidikan selama satu semester, untuk tingkat sarjana Strata 1.

Sejak berdiri tahun 1994, ACICIS saat ini telah bertempat di tiga lokasi yakni, Perth, Jakarta serta Yogyakarta dan telah membantu lebih dari 2.000 mahasiswa untuk belajar di Indonesia. ACICIS sendiri organisasi non-pemerintah yang memiliki sekretariat yang berlokasi di University of Western Australia, Perth, dan berkantor pusat di Universitas Murdoch Australia, serta di pimpin oleh sebuah National Reference Group yang terdiri dari para akademik senior di bidang studi Indonesia.

\footnotetext{
${ }^{2}$ https://www.acicis.edu.au/about-us/, diakses pada 15 Juni 2019, pukul 00.16 wib.
} 
Kini, Study Indonesia Programme (SIP) ACICIS merupakan salah satu program studi Indonesia utama yang memberikan kesempatan kepada para mahasiswa Australia, mahasiswa non-Australia ataupun perorangan, untuk belajar di Indonesia sekaligus mendapatkan kredit studi di universitas asal mereka. Untuk memberikan kesempatan kepada lebih banyak mahasiswa, ACICIS hingga saat ini telah berhasil bekerjasama dengan 24 universitas di Australia serta dua universitas di Inggris dan Belanda. ACICIS sendiri telah diakui oleh pemerintah Australia sebagai "model pendidikan dalam negeri yang sukses" hingga Asian Studies Association of Australia telah memberikan proposal agar model lembaga konsorsium ini diadaptasi untuk memberikan pengalaman studi dalam negeri dalam berbagai bahasa lainnya seperti Bahasa Arab, Vietnam, dan Hindi.

SIP terdiri atas 3 program utama yakni, program praktikum, pendidikan selama satu satu semester dan tur. Program praktikum bersama ACICIS biasanya diadakan selama 6 minggu yang dimulai dengan 2 minggu pertama belajar Bahasa Indonesia secara intensif lalu dilanjutkan dengan 4 minggu program praktikum yang dapat dipilih dari bidang bisnis, creative art \& desingn, studi pembangunan serta jurnalisme.

Untuk megikuti Semester Progamme, para mahasiswa dapat memilih dari 8 program semester yang di tawarkan ACICIS. Salah satu program terbaru ACICIS tawarkan adalah Agriculture Semester Program (ASP) yang dimulai pada Agustus 2016. Dalam ASP ini para mahasiswa memiliki kesempatan menempuh pendidikan di Institut Pertanian Bogor untuk mendalami ilmu agrobisnis, holtikultura, teknologi pangan, kehutanan dan masih banyak lagi. Selain itu, ACICIS juga membuka kesempatan bagi para ASP untuk mengikuti program praktikum di organisasi pertanian lokal dan internasional di Indonesia.

Seperti yang telah disebutkan sebelumnya, ACICIS juga menawarkan program tur pendidikan yang terdiri dari Indonesian School Tours, Indonesia from the Ground Up, Indonesian Language Short Course, serta Public Health Study Tour. Pada dasarnya keempat tur pendidikan ini diadakan untuk memberikan kesempatan lebih kepada para peserta ACICIS untuk mendalami pengetahuan mereka dan kehidupan politik, sosial, budaya serta pendidikan dan kesehatan di Indonesia yang dilengkapi dengan pengalaman langsung mengunjungi berbagai lokasi terkait serta berinteraksi dengan masyarakat secara langsung.

Pemerintah Australia telah menunjukkan komitmen mereka untuk mendukung proses studi Indonesia dengan memberikan Mobility Funding untuk para mahasiswa peserta ACICIS. Di tahun 2016, pemerintah Australia telah mengalokasikan dana sebesar 
AUD 1,5 juta untuk mendukung student mobility bagi mahasiswa Australia yang akan belajar di Indonesia periode 2016-2017. Dukungan finansial ini di bagi kedalam 303 mobilty grants dan 79 intership grants. ${ }^{3}$

\section{B. Rumusan Masalah}

Sesuai dengan pendahuluan diatas dapat ditarik perumusan masalah sebagai berikut: Bagaimana kerjasama antara Australia dengan Indonesia dalam sektor pendidikan melalui organisasi ACICIS?

\section{Tujuan}

Berdasarkan pokok permasalahan tersebut maka tujuan penelitian ini adalah untuk mengetahui pelaksanaan kerjasama antara Australia dengan Indonesia dalam sektor pendidikan melalui organisasi ACICIS. Kiranya penelitian ini dapat digunakan sebagai pengetahuan teoritis dan pengetahuan empiris dalam melakukan kerjasama internasional khususnya dalam sektor pendidikan.

\section{Metode Penelitian}

Metode penelitian yang digunakan dalam penelitian ini adalah metode penelitian kualitatif, yaitu sebuah cara/upaya untuk menekunkan pada aspek pemahaman secara mendalam pada suatu permasalahan. Penelitian kualitatif adalah penelitian riset yang bersifat deskripsi, cenderung menggunakan analisis dan lebih menonjolkan proses makna. Tujuan dari metode ini adalah pemahaman secara luas dan mendalam terhadap suatu permasalahan yang sedang dikaji. Sumber data yang digunakan adalah data sekunder (surat kabar, artikel ilmiah, internet, serta sumber valid lainnya). ${ }^{4}$

\section{E. Kerangka Teori}

Meningkatnya hubungan antar negara pada masa ini, sangat tepat rasanya menggunakan Teori Kerja Sama Internasional dalam penelitian ini, karena semua negara di dunia ini tidak dapat berdiri sendiri dalam memenuhi kebutuhan terlebih dalam meningkatkan perkembangan dan kemajuan negaranya. Perlu kerjasama dengan negara lain karena adanya saling ketergantuangan sesuai dengan kebutuhan negara masingmasing. Perkembangan situasi hubungan internasional ditandai dengan berbagai kerjasama internasional dan berkembangnya berbagai aspek diantaranya rasionalisme ekonomi diberbagai kawasan telah mebawa pengaruh semakin besarnya persoalan sosial

\footnotetext{
${ }^{3}$ http://www.buset-online.com/acicis-buka-peluang-mempelajari-indonesia/, diakses pada 15 Juni 2019, pukul 00.20 wib.

${ }^{4}$ https://www.djkn.kemenkeu.go.id/artikel/baca/12773/Memahami-Metode-Penelitian-Kualitatif.html, diakses pada 15 Juni 2019, pukul 09.15 wib.
} 
ekonomi yang lebih menyita perhatian negara-negara didunia melalui serangkaian kerjasama internasional.

Demikian halnya negara di dunia semakin memperkuat posisi saling ketergantungan secara global yang tampak semakin nyata dan titik beratnya adalah pada upaya meningkatkan kesejahteraan suatu bangsa yang dilandasi prinsip saling percaya, menghargai dan menghormati. Kerjasama dalam bidang ekonomi, politik, pendidikan, budaya, dan keamaan dapat dijalin oleh suatu negara dengan satu atau lebih negara lainnya.

Dari pengaturan substansinya, dapat dibedakan dala dua kategori berupa Law Making Treaties, yaitu perjanjian internasional yang mengandung kaidah-kaidah hukum yang dapat berlaku secara universal bagi anggota masyarakat bangsa-bangsa, sehingga demikian dikategorikan sebagi perjanjian-perjanjian internasonal yang berfungsi sebagai sumber langsung hukum internasional. Sedangkan perjanjian internasional yang digolongkan sebagai Treaty Contract mengandung ketentuan-ketentuan yang mengatur hubungan-hubungan atau persoalan-persoalan khusus antara pihak yang mengadakannya saja, sehingga hanya berlaku khusus bagi para peserta perjanjian. Oleh sebab itu, perjanjian-perjanjian internasional yang tergolong Treaty Contract tidak secara langsung menjadi sumber hukum internasional. ${ }^{5}$

\section{F. Pembahasan}

Australian Consortium for In Country Indonesian Studies (ACICIS) merupakan konsorsium pendidikan nasional yang inovatif, nirlaba, yang berdiri tahun 1994, yang didirikan untuk mengembangkan dan mengoordinasikan progam-progam studi semester panjang berkualitas tinggi di universitas-universitas mitra di Indonesia yang terbuka untuk orang Australia, non-Australia maupun perorangan. Melalui ACICIS ini para mahasiswa dapat memiliki pengalaman pendidikan terbaik di Indonesia, dengan kondisi lingkungan yang aman, dan mendukung. ACICIS saat ini memiliki 24 universitas anggota, serta dua anggota internasional yang berada di Inggris dan Belanda. ${ }^{6}$

\section{Kerjasama Australia dan Indonesia dalam Upaya Pengembangan Sektor Pendidikan Di Australia Melalui Organisasi ACICIS (Australian Consortium For In-Country Indonesian Studies)}

\footnotetext{
${ }^{5}$ Jackson,Robert dan Georg Sorensen. 2005. Pengantar Studi Hubungan Internasional. Yogyakarta: Pustaka Pelajar.

${ }^{6}$ Loc . Cit.
} 
Pendidikan merupakan pilar penting dalam hubungan bilateral antara Australia dan Indonesia. Terutama pendidikan dalam dalam lingkup perguruan tinggi, yang dilakukan oleh kedua belah pihak. Para mahasiswa merupakan aset penting karena mereka merupakan pemimpin masa depan bagi kedua negara. Mereka juga merupakan jembatan penghubung bagi hubungan yang lebih kuat dan lebih rekat antara Australia dan Indonesia. Para mahasiswa merupakan inti dari hubungan antar orang dengan orang antara kedua negara. ${ }^{7}$

Kerjasama pendidikan dalam tingkat perguruan tinggi ini di wujudkan melalui suatu organisasi/program yang bernama ACICIS (Australian Consortium for In Country Indonesian Studies). ACICIS ini didirikan oleh Professor David Hill dari Universitas Murdoch, Australia. ACICIS adalah organisasi nirlaba yang bertujuan untuk mengatasi rintangan yang dihadapi mahasiswa Australia yang berkuliah dan mendapatkan kredit mata kuliah dari universitas di Indonesia. ACICIS memfokuskan diri pada upaya-upaya untuk membangun pemahaman antarbudaya dengan membekali mahasiswa Australia dengan kemampuan untuk hidup di dunia yang multibudaya, meningkatkan kemampuan mereka untuk beradaptasi dilingkungan yang baru.

Misi yang dimiliki oleh organisasi ACICIS yakni, untuk meningkatkan jumlah mahasiswa Australia yang melakukan studi di perguruan tinggi Indonesia. Sedangkan visi yang dimiliki oleh ACICIS yakni, menjadi fasilitator tepercaya terkemuka Australia untuk pogram mobilitas pelajar internasional ke Indonesia. ${ }^{8}$

Progam dan kegiatan ACICIS diatur oleh National Reference Group yang terdiri dari akademisi senior Indonesia dan mahasiswa internasional yang mewakili semua yuridiksi negara bagian Australia, serta beberapa anggota undangan yang di tunjuk oleh National Reference Group, berdasarkan pengetahuan, keahlian, atau pengalaman profesional mereka.

National Reference Group bertanggung jawab untuk menyetujui dan memimpin dalam melaksanakan semua inisiatif dan kegiatan ACICIS, memantau kegiatan, dan keuangan konsorsium, menentukkan hal-hal kebijakan yang berkaitan dengan ACICIS, termasuk biaya yang harus dibayarkan oleh anggota konsorsium dan meratifikasi keputusan Direktur Konsorsium. ${ }^{9}$

\footnotetext{
$7 \quad$ https://internasional.republika.co.id/berita/internasional/asia/18/04/06/p6rv1c284-pendidikan-pilar-pentinghubungan-indonesia-dan-australia, diakses pada 15 Juni 2019, pukul 10.07 wib.

${ }^{8}$ Loc. Cit.

${ }^{9}$ https://www.acicis.edu.au/about-us/national-reference-group/, diakses pada 15 Juni 2019, pukul 10.23 wib.
} 
ACICIS ini sesuai dengan salah satu pilar penting dalam kemitraan komprehensif strategis Indonesia dan dan Australia yaitu pilar People to People Connection. Dengan mengikuti organisasi ACICIS ini tentunya akan memberikan begitu banyak manfaat bagi para peserta seperti, para mahasiswa Australia bisa meningkatkan kemampuan bahasa Indonesia mereka, begitupun dengan mahasiswa Indonesia juga dapat meningkatkan kemampuan bahasa Inggris mereka. Selain dari segi bahasa para mahasiswa Australia juga dapat mempelajari beragam ilmu pengetahuan baru di Indonesia misalnya seperti ilmu hukum, jurnalistik, pertanian, dll, sesuai dengan prodi yang mereka ambil. ACICIS ini juga bisa di jadikan batu loncatan bagi para peserta/mahasiswa untuk bisa bergabung dengan organisasi internasional lainnya.

\section{Penerapan Teori dalam Kerja Sama Antara Australia dan Indonesia}

Hubungan antara Australia dan Indonesia memiliki sejarah yang cukup panjang sejak zaman perjuangan kemerdekaan Indonesia. Australia merupakan salah satu dari sejumlah negara di dunia yang pertama mengakui hak Indonesia untuk merdeka. Dalam perkembangannya, hubungan bilateral antara Australia dan Indonesia mengalami pasang surut. Hal tersebut terjadi karena berbagai perbedaan yang ada diantara kedua negara, antara lain, perbedaan yang terkait dengan sistem politik, kondisi sosial, ekonomi, dan kebudayaan. Namun, fakta geografis yang menunjukkan bahwa kedua negara merupakan negara bertetangga menjadi faktor yang mendorong perlunya negara untuk berinteraksi (bekerjasama) secara kondusif guna menjaga stabilitas kawasan.

Salah satu kerjasama yang dilakukan oleh kedua belah pihak adalah kerjasama dalam sektor pendidikan. ACICIS adalah salah satu wujud nyata kerjasama antara Australia dan Indonesia dalam sektor pendidikan meskipun ACICIS ini sifatnya people to people. Namun, pihak Australia dan Indonesia pada tahun 2014 telah melakukan penandatanganan Memorandum of Understanding (MoU) di bidang pendidikan yang resmi ditandatangani kedua negara di Vientiane, Laos pada 12 September $2014 .{ }^{10} \mathrm{MoU}$ tersebut, merupakan bukti bahwa kedua negara ingin semakin meningkatkan kerjasama dalam sektor pendidikan.

ACICIS terdiri dari 24 universitas yang ada di Australia serta dua universitas yang berada di Inggris dan Belanda diantaranya, The Australian National University, 
Curtin University, Charles Darwin University, Edith Cowan University, Flinders University, Griffith University, La Trobe Univesity, Leiden University, Macquarie University, Monash University, Murdoch University, Queensland University of Technology, RMIT University, SOAS University of London, The University of Adelaide, The University of Melbourne, The University of Queenslad, The University of Sydney, The University of Western Australia, University of New England, University of New South Wales, University of South Australia, University of Tasmania, University of Technology Sydney, University of the Sunshine Coast, dan Western Sydney University.

26 universitas tersebut bekerja sama dengan 10 universitas yang ada di Indonesia diantaranya, Universitas Atma Jaya, Institut pertanian Bogor (IPB), Universitas Gajah Mada (UGM), Universitas Islam Indonesia (UII), Universitas Muhammadiyah Malang (UMM), Universitas Parahyangan, Universitas Sanata Dharma, Universitas katolik Satya Wacana, Universitas Udayana, Universitas, Indonesia. Sedangkan untuk bidang sudi yang dipelajari dalam organisasi ACICIS diantaranya, pertanian, seni \& humaniora, Bisnis \& perdagangan, seni \& desain kreatif, studi pembangunan, media \& komunikasi, bahasa Indonesia, hubungan internasional, jurnalistik, hukum, kesehatan masyarakat, hubungan masyarakat, science, dan pariwisata.

Universitas di Australia maupun universitas internasional lainnya juga dapat mendaftarkan diri untuk menjadi anggota konsorsium ACICIS. Bagi universitas yang bergabung dalam konsorsium ini pastinya akan mendapatkan beberapa keuntungan. Ini merupakan cara yang efektif bagi suatu universitas untuk mengirimkan mahasiswanya ke Indonesia untuk melakukan studi dengan pengawasan di bawah ACICIS. Biaya bergabung awal untuk keanggotaan ACICIS adalah AUD 9.845. Biaya ini hanya dibayarkan ketika sebuah universitas pertama kali bergabung dengan konsorsium ACICIS. Untuk retribusi keanggotaan tahunannya, setiap universitas yang bergabung diwajibkan untuk membayar uang sebesar AUD 9.845, pada tanggal 1 September setiap tahunnya. $^{11}$

Kerjasama dalam sektor pendidikan ini dilakukan dengan mengirimkan beberapa mahasiswa yang ada di Australia, sesuai dengan program yang telah di pilih oleh setiap mahasiswa. Dalam organisasi ACICIS ini, terdapat beberapa program yang bisa diikuti oleh para mahasiswa diantaranya, Agriculture Semester Program (ASP), yang memungkinkan bagi para mahasiswa untuk mengambil beberapa program studi yang ada

\footnotetext{
${ }^{11}$ https://www.acicis.edu.au/about-us/join-acicis-consortium/,diakses pada 17 Juni 2019, pukul 17.00 wib.
} 
di IPB, termasuk mata pelajaran dalam agribisnis, agronomi dan hortikultura, perlindungan tanaman, ilmu dan teknologi pangan. ${ }^{12}$. Development Studies Immersion (DSIP), merupakan program studi pembangunan masyarakat selama satu semester yang diselenggarakan di Universitas Gajah Mada. ${ }^{13}$ East Java Field Study (EJFS), program ini akan diselenggarakan di Universitas Muhammadiyah Malang. ${ }^{14}$ Flexible Language, Immerson (FLIP), program ini dilaksanakan di UGM. ${ }^{15}$ Indonesian Language Teacher Immersion (ILTI), program ini merupakan suatu program yang dirancang untuk meghasilkan guru bahasa Indonesia berkualitas tinggi, dimana pelaksanaannya diselengarakan di Universitas Sananta Dharma Yogyakarta. ${ }^{16}$ Internastional Relation (IRP), program ini merupakan program yang khusus mepelajari mengenai mata kuliah hubungan internasional, dimana pelaksanaannya dilaksanankan di Universitas Katolik Parahyangan Bandung, selama satu semester. ${ }^{17}$ Indonesian Business Law \& Society (IBLS), merupakan program yang memberikan para mahasiswa pemahaman yang komprehensif tentang bisnis, hukum dan masyarakat Indonesia ditingkat regional maupun internasional yang dilihat dari perspektif Indonesia, program ini dilaksanakan di Universitas Islam Indonesia (UII) Yogyakarta. ${ }^{18}$ West Java Field Study Program (WJFS), program ini dilaksanakan di Universitas Katolik Parahyangan (UNPAR). ${ }^{19}$

Selain beberapa semester progamme yang telah disebutkan sebelumnya, ACICIS juga menawarkan practicum programs terhadap para peserta ACICIS, program praktikum bersama ACICIS biasanya diadakan selama 6 minggu yang dimulai dengan 2 minggu pertama belajar bahasa Indonesia secara intensif kemudian dilanjutkan dengan 4 minggu program praktikum sesuai dengan prodi yang diambil. Program praktikum yang di tawarkan oleh ACICIS diantaranya, Agriculture Professional Practicum (APP), Business Professional Practicum (BPP), Creative Arts and Desugn Professional

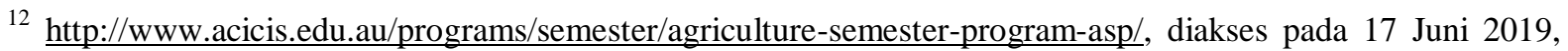
pukul 18.12 wib.

13 https://www.acicis.edu.au/programs/semester/development-studies-immersion-dsip/, diakses pada 17 Juni 2019, pukul 19.15 wib.

${ }^{14}$ https://www.acicis.edu.au/programs/semester/east-java-field-study-ejfs/, diakses pada 17 Juni 2019, pukul 19.23 wib.

${ }^{15} \mathrm{https}: / /$ www.acicis.edu.au/programs/semester/flexible-language-immersion-flip/, diakses pada 18 Juni 2019, pukul 16.05 wib.

${ }^{16}$ https://www.acicis.edu.au/programs/semester/indonesian-language-teacher-immersion-ilti/, diakses pada 18 Juni 2019, pukul 16.20 wib.

${ }^{17} \mathrm{https} / / / \mathrm{www} . a c i c i s . e d u . a u /$ programs/semester/international-relations-irp/, diakses pada 18 Juni 2019, pukul 17.03 wib.

${ }^{18}$ https://www.acicis.edu.au/programs/semester/indonesian-business-law-society-ibls/, diakses pada 18 Juni 2019, pukul 20.17 wib.

${ }^{19} \mathrm{https} / / /$ www.acicis.edu.au/programs/semester/west-java-field-studies-wjfs/, diakses pada 18 Juni 2019, pukul 20.30 wib. 
Parcticum (CADPP), Development Studies Professional Practicum (DSPP), Journalism Professinal Practicum (JPP), Law Proffesional Practicum (LPP), serta Sustainable TourismProfesional Practicum (STPP). ${ }^{20}$

Organisasi ACICIS juga menawarkan program tur pendidikan yang terdiri dari Indonesia School Tours, Indonesia From the Ground Up (IFGU), Indonesian Language Short Course (ILSC), serta Public Health Study Tour (PHST). Pada dasarnya tur pendidikan tersebut diadakan untuk memberikan kesempatan lebih kepada peserta ACICIS untuk mendalami pengetahuan mereka dan kehidupan politik, sosial, budaya serta pendidikan dan kesehatan di Indonesia, dengan pengalaman langsung mengunjungi berbagai lokasi terkait serta interaksi dengan masyarakat. ${ }^{21}$ Organisasi ACICIS ini, memungkinkan para mahasiswa Australia, non-Australia, maupun perorangan untuk dapat merasakan pendidikan di Indonesia berdasarkan prodi dan keperluan masingmasing peserta, serta semua program yang ada di ACICIS ini pelaksanaannya berada dibawah pengawasan ACICIS dan dilaksanakan berdasarkan MoU yang telah disepakati oleh kedua negara sebelumnya.

\section{G. Kesimpulan}

Dari uraian diatas, maka dapat disimpulkan bahwa negara Australia dan Indonesia merupakan negara yang telah melakukan hubungan bilateral atau kerjasama sudah sejak lama. Salah satu kerjasama yang kini tengah gencar dilaksanakan oleh kedua belah pihak adalah kerjasama dalam sektor pendidikan. Kerjasama dalam sektor pendidikan ini diwujudkan dengan dibentuknya organisasi ACICIS (Australian Consortium for InCountry Indonesian Studies) pada tahun 1994. ACICIS merupakan sebuah lembaga konsorsium non-profit yang inovatif, nirlaba, serta bertujuan untuk memudahkan para mahasiswa asing khususnya mereka yang berasal dari Australia untuk melakukan studi di universitas-universitas mitra di Indonesia.

Melalui ACICIS ini para mahasiswa mampu mendapatkan pengalaman pendidikan terbaik di Indonesia, dengan kondisi lingkungan yang aman dan mendukung. Kerjasama ini juga di perkuat dengan penendatanganan MoU antara kedua belah pihak pada tahun 2014, di Vientiane, Laos. Dalam organisasi ACICIS ini terdapat beberapa program yang dilaksankan seperti program praktikum, program pendidikan selama satu semester serta program tur. Program praktikum bersama ACICIS biasanya diadakan selama 6 minggu

\footnotetext{
${ }^{20} \mathrm{https}$ ://www.acicis.edu.au/resources/, diakses pada 19 Januari 2019, pukul 17.08 wib.

${ }^{21}$ Ibid.
} 
yang dimulai dengan 2 minggu pertama belajar Bahasa Indonesia secara intensif lalu dilanjutkan dengan 4 minggu program praktikum sesuai dengan prodi yang telah dipilih sebelumnya.

Untuk megikuti Semester Progamme, para mahasiswa dapat memilih dari 8 program semester yang di tawarkan ACICIS. Salah satu program terbaru ACICIS tawarkan adalah Agriculture Semester Program (ASP) yang dimulai pada Agustus 2016. Dalam ASP ini para mahasiswa memiliki kesempatan menempuh pendidikan di Institut Pertanian Bogor untuk mendalami ilmu agrobisnis, holtikultura, teknologi pangan, kehutanan dan masih banyak lagi. Selain itu, ACICIS juga membuka kesempatan bagi para ASP untuk mengikuti program praktikum di organisasi pertanian lokal dan internasional di Indonesia.

Seperti yang telah disebutkan sebelumnya, ACICIS juga menawarkan program tur pendidikan yang terdiri dari Indonesian School Tours, Indonesia from the Ground Up, Indonesian Language Short Course, serta Public Health Study Tour. Pada dasarnya keempat tur pendidikan ini diadakan untuk memberikan kesempatan lebih kepada para peserta ACICIS untuk mendalami pengetahuan mereka dan kehidupan politik, sosial, budaya serta pendidikan dan kesehatan di Indonesia yang dilengkapi dengan pengalaman langsung mengunjungi berbagai lokasi terkait serta berinteraksi dengan masyarakat secara langsung. 
Jackson,Robert dan Georg Sorensen. 2005. Pengantar Studi Hubungan Internasional. Yogyakarta: Pustaka Pelajar.

Kemenristekdikti, "Pengembangan Iptek dan Pendidikan Tinggi di Era Revolusi Industri 4.0", diakses dari https://www.ristekdikti.go.id/siaran-pers/pengembangan-iptek-danpendidikan-tinggi-di-era-revolusi-industri-4-0/, diakses pada 15 Juni 2019.

https://www.acicis.edu.au/about-us/, diakses pada 15 Juni 2019.

Buset, "ACICIS Buka Peluang Mempelajari Indonesia", di akses dari http://www.busetonline.com/acicis-buka-peluang-mempelajari-indonesia/, diakses pada 15 Juni 2019.

Artikel DJKN, "Memahami Metode Penelitian Kualitatif", diakses dari https://www.djkn.kemenkeu.go.id/artikel/baca/12773/Memahami-Metode-PenelitianKualitatif.html, diakses pada 15 Juni 2019.

Yudha Manggala P Putra, "Pendidikan Pilar Penting Hubungan Indonesia dan Australia", diakses dari https://internasional.republika.co.id/berita/internasional/asia/18/04/06/p6rv1c284pendidikan-pilar-penting-hubungan-indonesia-dan-australia, diakses pada 15 Juni 2019.

https://www.acicis.edu.au/about-us/national-reference-group/, diakses pada 15 Juni 2019.

Angga Indrawan, "RI-Australia Sepakati MoU Bidang Pendidikan", diakses dari https://www.republika.co.id/berita/nasional/umum/14/09/12/nbsi4d-riaustralia-sepakatimou-bidang-pendidikan, diakses pada 16 Juni 2019.

https://www.acicis.edu.au/about-us/join-acicis-consortium/,diakses pada 17 Juni 2019.

http://www.acicis.edu.au/programs/semester/agriculture-semester-program-asp/, diakses pada 17 Juni 2019.

https://www.acicis.edu.au/programs/semester/development-studies-immersion-dsip/, diakses pada 17 Juni 2019.

https://www.acicis.edu.au/programs/semester/east-java-field-study-ejfs/, diakses pada 17 Juni 2019. 
https://www.acicis.edu.au/programs/semester/flexible-language-immersion-flip/, $\quad$ diakses pada 18 Juni 2019.

https://www.acicis.edu.au/programs/semester/indonesian-language-teacher-immersion-ilti/, diakses pada 18 Juni 2019.

https://www.acicis.edu.au/programs/semester/international-relations-irp/, diakses pada 18 Juni 2019.

https://www.acicis.edu.au/programs/semester/indonesian-business-law-society-ibls/, diakses pada 18 Juni 2019.

https://www.acicis.edu.au/programs/semester/west-java-field-studies-wjfs/, diakses pada 18 Juni 2019.

https://www.acicis.edu.au/resources/, diakses pada 19 Januari 2019. 